\title{
Phenological, Physiological and yield markers as efficient tools to identify drought tolerant rice genotypes in Eastern India
}

Soumya Kumar Sahoo ${ }^{2}$, Goutam Kumar Dash', Arti Guhey ${ }^{2}$, Mirza Jaynul Baig ${ }^{1}$, Madhusmita Barik ${ }^{1}$, Selukash Parida ${ }^{1}$, Padmini Swain1

\section{Corresponding Author:}

\section{Padmini Swain}

Crop Physiology and Biochemistry Division

ICAR-National Rice Research Institute, Cuttack, 753006, India

Tel- 91-671-2367768-83; Fax: 91-671-2367663

Email pswaincrri@gmail.com

\section{Author affiliation:}

${ }^{1}$ Crop Physiology and Biochemistry Division

ICAR-National Rice Research Institute, Cuttack-753006, India

${ }^{2}$ Department of Plant Physiology,

Indira Gandhi Krishi Viswavidyalaya, Raipur

Chattissgarh-492012, India

Declarations:

Funding No funding was received.

Conflicts of interest/Competing interests There is no conflict of interest in the manuscript.

Ethics approval NA

Availability of data and material All the required data are given in the manuscript

Code availability NA

Authors' contributions: Both SKS and GKD contributed equally to the manuscript as first authors. SKS, GKD and PS designed the experiment. SKS, MB and SP carried out the experiment. Data compilation, analysis and preparation of manuscript was done by SKS and GKD, Review of manuscript was done by AG, MJB and PS. Acknowledgements: This study was financially supported by Jawaharlal Nehru Scholarship for doctoral studies, Jawaharlal Nehru memorial Fund, New Delhi. 


\section{ABSTRACT}

Rice production is severely threatened by drought stress in Eastern India. To develop drought tolerant varieties, selection of donors for breeding programme is crucial. Twenty one selected rice genotypes including both tolerant and sensitive to drought were grown under well-watered and drought stress conditions in dry seasons of two successive years of 2017 and 2018. Leaf water potential, relative water content displayed significant difference among the genotypes during vegetative screening. At reproductive stage drought screening, days to 50\% flowering was delayed in all genotypes except N22 and Anjali (showed early flowering) however grain yield and other yield related traits decreased significantly compared to well-watered condition. Correlation analysis of phenological and yield related traits with grain yield revealed that tiller numbers and panicle numbers are highly correlated with grain yield both under well-watered and water stress conditions and contributes maximum towards grain yield. The dendrogram grouped Mahamaya, Sahabhagidhan, Poornima, IBD 1, Hazaridhan, Samleshwari and Danteshwari into one cluster which performed better under water stress conditions and had grain yield more than 1.69 tha $^{-1}$. Sahabhagidhan, Poornima, Vandana, and N22 displayed tolerance to drought both under vegetative and reproductive conditions which could be a good selection for the breeders to develop drought tolerant rice cultivars for eastern region of India.

Key words: Drought stress, Reproductive stage

\section{INTRODUCTION}

Although rice grows better in sufficient water available conditions, yet it has better adaptability to highly diverse ecological condition. India is the centre of rice diversity (Ray et al., 2015) and the crop is cultivated in about 43 million hectares of land with 110 million tons of milled rice production was recorded as per 2016-17 statistical reports. About 40\% of rice producing area of India is rainfed, out of which $70 \%$ is present in eastern India in the states of Odisha, Chhattisgarh, West Bengal, Bihar, Jharkhand and Eastern Uttar Pradesh. The total rainfed area of this region comprises $77 \%$ of lowland and $23 \%$ of upland out of which $52 \%$ of lowland and entire area of upland are affected by drought (Pathak et al 2018). ). In the year 2017, India had approximately $43 \mathrm{~m}$ ha rice growing area (Keerlery 2020), nearly $60 \%$ of which were in Eastern India (IRRI, 1997 ) and only rainfed rice growing area of Eastern India accounts for $12.9 \mathrm{mha}$ (Lal et al. 2017). These areas characterized with often failure of rain or a long spell between two rains, hence drought stress can appear at any period of crop growing stage that may be at seedling, vegetative, and reproductive stage or it can be intermittent drought depending upon the rainfall pattern and distribution. Although drought at reproductive stage is more detrimental, still drought at vegetative stage also a determining factor for reproductive growth in rice.

Water requirement of rice crop depends on field conditions, cropping seasons and growth stages (MARDI, 2009). Since, rice plants require water throughout their growth period, there are certain critical growth stages when drought stress can dramatically reduce the grain yield (Bajji et al., 2001; Zhou et al., 2007). During vegetative stage, drought stress decrease the leaf and tiller formation that ultimately reduce yield by affecting panicle development (Swain et al. 2017; Singh et al. 2017). However, when drought stress occurs during reproductive growth phase, it remarkably reduces rice grain yield due to abortion of ovule and formation of partially filled grains (Pantuwan et al. 2002a). 
Drought stress tolerance can be potentially measured through physiological and phenological parameters. Plant metabolism primarily dependent on water status and the best way to determine plant water status is through measurement of relative water content (RWC) and leaf water potential (LWP). Maintenance of proper plant water status The relative water content (RWC) is crucial physiological parameter that refers to the degree of cell or tissue hydration which is responsible for maintaining growth activities that results in better grain yield in rice (Silva et al. 2007). Measurement of RWC indicates the stress intensity and act as a screening tool for plant water status (Hassanzadeh et al. 2009). Gutierrez et al. (2010) and Manickavelu et al. (2006) investigated on RWC, which is highly correlated with morphological and yield traits viz., plant height, days to flowering, panicle length and harvest index besides grain yield. Several reports showed that higher decrease in LWP was observed in drought susceptible genotypes than the tolerant ones (Silva et al., 2010; Silvestre et al., 2017). The lower leaf water potentials leads to reduced turgor, stomatal conductance and photosynthesis, and thus eventually reduce grain yield (Akbarian et al., 2011; Amini et al., 2014). Standard evaluation system (SES) score (drought score and drought recovery score) is expressed as an elective way to deal with plant drought tolerance (Fen et al. 2015). Drought score taken at seedling stage is commonly not a good yield determining index (Mitchell et al., 1998) but at later growth stages it is considered as an essential parameters for drought screening (IRRI, 2014). Drought score and drought recovery score measurement is a convenient way to determine the degree of tolerance to oxidative damage in plants and show lack of hydration of the plant tissue related with its RWC (Cabuslay et al., 1999; Cabuslay et al 2002). Zhu (2002) and Mishra (2005) documented that under drought stress shoot growth and plant height reduction is a very common morph-physiological adaptation to water stress and is crucial for survival practice. Water deficiency, reduces plant height and tillers number (Zhang et al., 2009). The number of tillers is also linked with leaf rolling score, drought score and proline accumulation. So, lower tiller production during water stress may be a determinant of drought tolerance (Fen et al., 2015).

Drought decrease rice biomass accumulation at vegetative stage (Zhang et al., 2018), that results in grain yield reduction due to lowered filled grain number at reproductive stage (Fukai et al., 1999). In rice, under drought low grain yield is mainly due to the reduced number of filled spikelets per panicle without a substantial change in the number of spikelets per panicle (EKANAYAKE et al., 1989; Wei et al., 2014). Liu et al. (2006) reported that flowering stage is more vulnerable to water limited condition than any other developmental stage. Water stress at the booting (Pantuwan et al., 2002) and flowering stages interfere in floret initiation, leading to reduction in number of panicles per plant, grain filling percentage, spikelet sterility and decreased 1000 grain weight (Nour et al., 1995 and Fabre et al., 2005) which lead to poor grain yield in rice (Acuna et al., 2008). In the present study, twenty one popular genotypes are evaluated both under vegetative and reproductive stage drought to identify suitable donors for breeding programme.

\section{MATERIALS AND METHODS}

The experiment was conducted taking twenty one rice genotypes (including tolerant check Sahabhagidhan and susceptible check IR 20) to study their response towards drought stress both at vegetative and reproductive stage during dry season of 2017 and 2018 at the experimental field of ICAR-National Rice

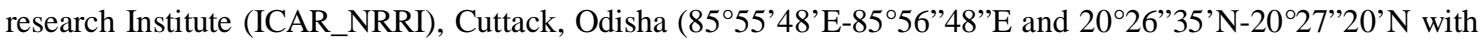
the general elevation of $24 \mathrm{~m}$ above the MSL). Out of twenty one genotypes, seven genotypes were native to 
112 Chhattisgarh and were collected from Gene bank of Indira Gandhi Krishi Vishwavidyalaya, Raipur and rest

113 fourteen genotypes were collected from Gene bank of ICAR- NRRI.

114 Table1 Information of the rice genotypes used in the experiment

115

\begin{tabular}{|l|l|l|l|l|l|}
\hline SI.No. & Genotype & Origin & Sl.No. & Genotype & Origin \\
\hline 1 & Danteshwari & Chhattisgarh & 12 & Kalinga-III & Odisha \\
\hline 2 & Mahamaya & Chhattisgarh & 13 & Vandana & Odisha \\
\hline 3 & MTU-1010 & Andhra Pradesh & 14 & Satyabhama & Odisha \\
\hline 4 & Samleshwari & Chhattisgarh & 15 & Anjali & Odisha \\
\hline 5 & Poornima & Chhattisgarh & 16 & CR Dhan-40 & Odisha \\
\hline 6 & IBD 1 & Chhattisgarh & 17 & N-22 & Uttar Pradesh \\
\hline 7 & Safri 17 & Chhattisgarh & 18 & IR-20 & Philippines \\
\hline 8 & Swarna & Andhra Pradesh & 19 & Virendra & Odisha \\
\hline 9 & IR 64 & Philippines & 20 & Vanaprabha & Odisha \\
\hline 10 & Sahabhagidhan & Odisha & 21 & Hazaridhan & Jharkhand \\
\hline 11 & Khandagiri & Odisha & & & \\
\hline
\end{tabular}

\section{Plant growth and treatments}

The genotypes were grown in field both under well-watered (WW) and drought stress (DS) conditions in randomised block design with three replications. Two to three seeds were sown per hill at a depth of $2 \mathrm{~cm}$ with a spacing of $20 \mathrm{~cm}$ between rows and $15 \mathrm{~cm}$ in between hills. In both the growing seasons; well-watered plot was maintained with nearly $5 \mathrm{~cm}$ standing water from 30 days of germination to till maturity. To impose water stress, two separate experiments were conducted: vegetative stage screening (VS) and Reproductive stage screening (RS) for two consecutive years 2017 and 2018.

Vegetative stage drought stress was imposed by withholding irrigation for a period of 30 days, when seedlings were 30 days old. After 30 days of stress period (60 DAG), drought stress was released by irrigating the experimental field. Relative water content (Schonfeld et al. 1988), and leaf water potential Turner (1988) was recorded at the end of the stress. Drought score and drought recovery score was recorded according to Standard Evaluation System for rice (IRRI, 2002).

To impose stress at reproductive stage, irrigation was withdrawn 10 days before flowering and surface irrigation was provided till when soil moisture content dropped below 17\% and soil moisture tension dropped below $-65 \mathrm{kPa}$. To syncronize flowering dates, the genotypes were divided into four groups and staggered planting was adopted. Observations like days to 50\% flowering, plant height, tiller number grain yield and yield attributes such as panicle number, total dry matter, harvest index, fertility percentage and 1000 test grain weight were recorded after maturity (Yoshida et al. 1981). 


\section{7}

The soil of both the fields was sandy clay loam, moderately acidic $\mathrm{pH}(4.5-5.5)$ with medium organic carbon content $(0.5-0.75 \%)$. The recommended fertilizers doses of $\mathrm{N} \mathrm{P}_{2} \mathrm{O}_{5}: \mathrm{K}_{2} \mathrm{O} @ 80: 60: 60 \mathrm{~kg} \mathrm{ha}^{-1}$ in the form of urea, DAP and MOP, respectively was applied and plant protection measures were used as and when required during the crop growth period.

To assess the intensity of drought stress, soil moisture content (SMC) was measured using time domain refractometer (TDR) from a soil depth of $15 \mathrm{~cm}$ and $30 \mathrm{~cm}$ at an interval of 5 days after withdrawal of irrigation. Soil moisture potential (SMP) was observed daily from a soil depth of $15 \mathrm{~cm}$ and $30 \mathrm{~cm}$ using tensiometer and water table depth was measured installing piezometers in the experimental plots.

\section{Statistical analysis}

The obtained phenological, physiological and yield related data were calculated and scatter plots were constructed by using Microsoft excel. Statistical comparison between variance was carried out by ANOVA (Analysis of variance) among the genotypes and the water treatments using CROPSTAT ver 7.2. Correlation among the different traits were determined by using SPSS package ver23. The dendrogram was constructed using XLSTAT evolution 2020.1.1.

\section{RESULTS AND DISCUSSION}

The performance of the twenty one rice genotypes were evaluated under well-watered (WW) and drought stress (DS) conditions during dry seasons of 2017 and 2018. The results of the phenological, physiological and yield attributes were discussed on the basis of pooled data, obtained from results of 2017 and 2018.

\section{Soil moisture status as affected by drought stress}

During drought stress period at the vegetative stage growth period (30-60 DAG), the SMC and SMP were decreased and WTD was dropped with the increase in the duration of stress period in both the dry seasons. During dry season 2017, at 36-38 DAG, the crop received a 55mm of rainfall and during dry season 2018, at 58 DAG the crop received $12 \mathrm{~mm}$ of rainfall. (Fig 1 \& 2). At $15 \mathrm{~cm}$ soil depth, the SMC decreased to $13.60 \%$ and $14.35 \%$ whereas SMP decreased to $-51.50 \mathrm{kPa}$ and $-56.27 \mathrm{kPa}$ during dry season of 2017 and 2018 respectively. At $30 \mathrm{~cm}$ of soil depth the SMC decreased to $15.60 \%$ and $17.75 \%$, and SMP reached up to $-47.83 \mathrm{kPa}$ and $54.55 \mathrm{kPa}$ during dry seasons 2017 and 2018 respectively (Fig 3 \& 4). WTD dropped below $102 \mathrm{~cm}$ and $97 \mathrm{~cm}$ in 2017 and 2018 respectively. From the SMC, SMP and WTD data, it is evident that the crop had experienced moderate to severe drought stress during the vegetative stage stress period.

\section{Phenological and Physiological traits as affected by water stress}

In this study, the drought response of 21 rice genotypes for two years were evaluated based on SES score (Table 2). 
Table 2 Standard Evaluation System (SES) score for drought in dry seasons of 2017 and 2018.

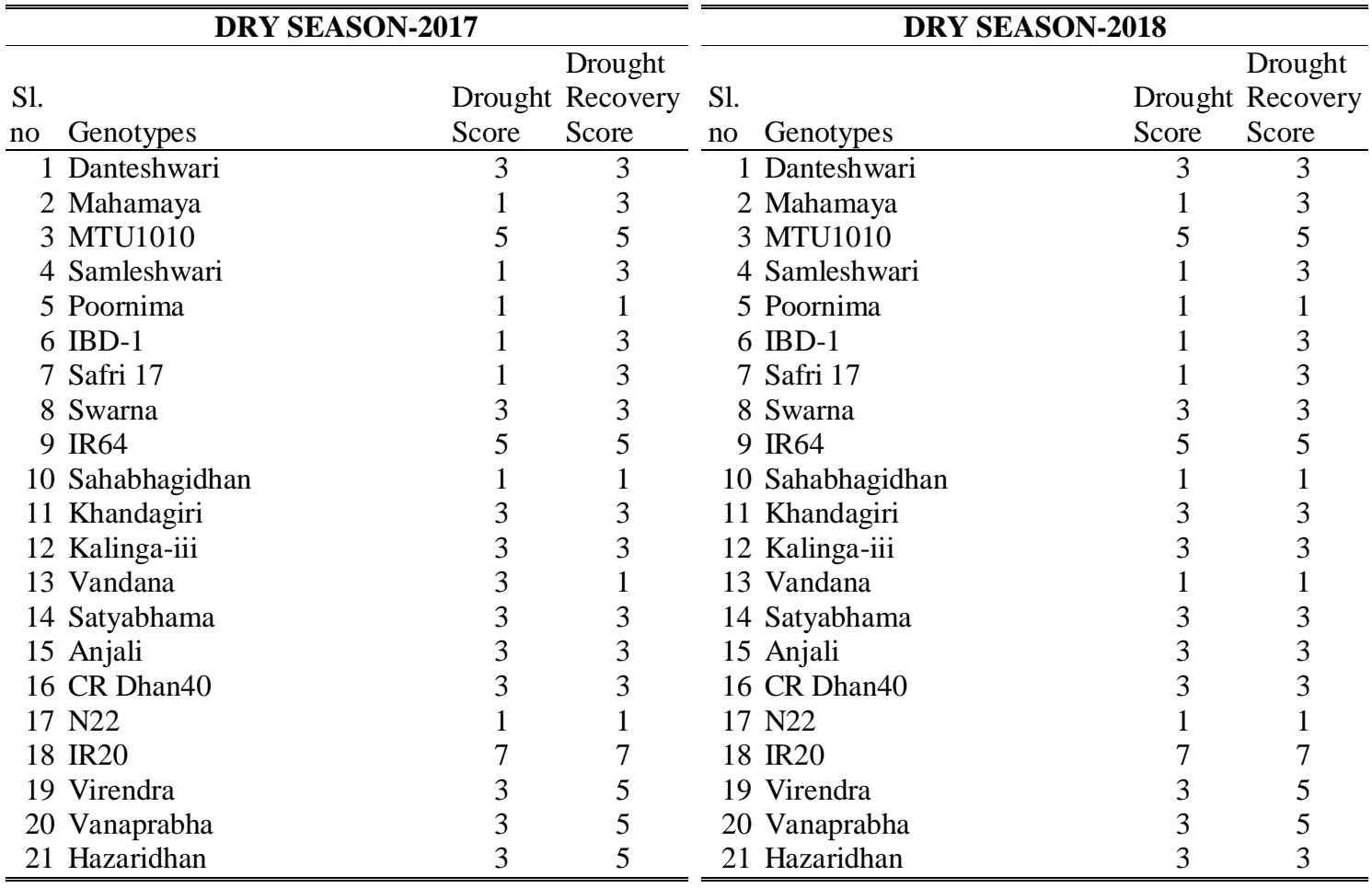
and N22) had SES drought score '1', 11 genotypes (Vandana, Danteshwari, Swarna, Khandagiri, Kalinga III, Satyabhama, Anjali, CR Dhan 40, Virendra, Vanaprabha, Hazaridhan) had '3' score, two genotypes (MTU 1010 and IR 64) had ' 5 ' score and IR 20 had '7' score in both the seasons, however, no genotypes had score '0' and '9' (Table 2). After 24 hrs of stress release, 4 genotypes (Sahabhagidhan, Poornima, Vandana, and N22) recovered with score '1', 11 genotypes (Danteshwari, Mahamaya, Samleshwari, IBD-1, Safri 17, Swarna, Khandagiri, Kalinga III, Satyabhama, Anjali, CR Dhan 40) recovered with score '3', 4 genotypes (IR 64, Virendra, Vanaprabha, Hazaridhan) recovered with score '5' and IR20 did not recovered in both the seasons (Table 2).

(Fig 5 and 6). Mahamaya, Samaleswari, Poornima, IBD-1, Safri 17, Sahabhagidhan and N22 had higher LWP (>-3.50 MPa) with more than 70\% leaf RWC under drought condition whereas MTU1010, IR 64 and IR 20 had lowest LWP $(<-4.5 \mathrm{MPa})$ with less than $60 \%$ RWC.

In DS condition, maximum DFF was recorded in susceptible check IR-20 (112.33 days) followed by Swarna (104 days) and IR64 (96.00days), whereas N22 (59.17 days) took minimum days to attain flowering followed by Anjali (63.5 days) and Kalinga III (64.50 days) (Fig 7). All genotypes except N22 and Anjali delayed in their DFF in DS as compared to WW condition however maximum delayed was observed in IR64 and IR-20 with 9.33 days ( $10.77 \%$ and $9.06 \%$ ) followed by MTU1010 with 8.17 days (9.78\%) and Swarna with 
191

192

and 2.00\%.). As mentioned earlier Anjali and N22 flowered early by 7.17days (10.14\%) and 5days (7.79\%) respectively under DS condition.

\section{Effect of water stress treatments on grain yield and yields attributes}

Results of ANOVA (Table 3) indicated significant variation for the measured nine traits (PH, TN, PN, TDM, GY, RYR, HI, GF\%, and GW) in dry seasons of both the year 2017 and 2018 among the genotypes and between the water treatments ranging from $3.39 \%$ for GW to $62.19 \%$ for GY. The pooled data of two dry seasons showed that grain yield suffered a mean yield loss of $62.19 \%\left(2.43 \mathrm{tha}^{-1}\right)$ and associated reductions in PH by $11.87 \%(12.07 \mathrm{~cm})$, TN by $25.72 \%$ (77.64 no. per $\left.\mathrm{m}^{2}\right)$, PN by $32.68 \%$ (123.15 no. per $\mathrm{m}^{2}$ ), TDM by $54.80 \%\left(6.33\right.$ tha $\left.^{-1}\right)$, HI by $19.15 \%(0.06)$, GF\% by $43.33 \%(35.30 \%)$ and GW by $3.39 \%(0.76 \mathrm{~g})$ under DS as compared to WW condition.

\section{The performance of tested genotypes in response to drought stress}

The results related to grain yield and yield attributes of rice genotypes under well-watered and drought stress conditions have been presented in Table 3. Under DS condition, higher grain yield was recorded in Mahamaya (2.42 t.ha $\left.{ }^{-1}\right)$, Samleshswari (2.05 t.ha $\left.{ }^{-1}\right)$, Sahabhagidhan and Danteswari (2.00 t.ha $\left.{ }^{-1}\right)$ while lowest grain yield was recorded in susceptible check IR20 (0.66 t.ha $\left.{ }^{-1}\right)$ followed by IR64 (0.76 t.ha $\left.{ }^{-1}\right)$ and MTU 1010 (0.86 t.ha $\left.{ }^{-1}\right)$. Minimum RYR was exhibited by Danteswari (39.11\%), Poornima (42.67\%) and Samleshwari (42.88\%) while maximum RYR was observed in susceptible check IR20 (86.28\%), IR64 (85.01\%) and MTU1010 (78.66\%) under DS condition over WW condition. The reduction in grain yield under DS condition resulted due to consistent and significant reduction in PH, TN, PN, TDM, HI, GF\%, and GW in comparison to WW condition. The minimum reduction in PH was exhibited by tolerant check Sahabhagidhan (3.38\%) followed by Poornima and Samleshwari while, maximum reduction was recorded in susceptible check IR-20 by $30.46 \mathrm{~cm}(29.14 \%)$ under DS as compared to WW condition. Similarly, the percentage reduction in TN was varied from $6.47 \%$ (Vandana) to $51.15 \%$ (IR64) under DS as compared to WW condition. Mahamaya, Danteshwari and Sahabhagidhan had PN >300 nos. $\mathrm{m}^{-2}$ whereas, susceptible check IR20 (114.89 nos. $\left.\mathrm{m}^{-2}\right)$ attained lowest value in DS condition with maximum percentage reduction $(71.09 \%)$ compared to WW condition. Danteshwari followed by Anjali and Satyabhama showed least reduction (7.97-17.22 \%) in $\mathrm{PNm}^{-2}$ in DS as compared to WW condition. Under DS condition Mahamaya, Samleshwari and Danteshwari had highest TDM (8.70 - 6.27 tha $^{-1}$ ) while lowest was recorded by susceptible check IR20 (3.60 t.ha $\left.{ }^{-1}\right)$. Comparatively less reduction in TDM was observed in Danteshwari, Samleshwari and Mahamaya with 21.37\%, 36.39\% and $37.92 \%$ and higher reduction was recorded in Swarna, MTU1010 and IR64 with 73.79, 72.35\% 72.29\% respectively in DS condition as compared to WW condition. In DS condition, maximum HI was recorded in N22, Poornima and Kalinga III (>0.334) whereas, minimum HI was observed in IR20, IR64 and MTU 1010 $(<0.212)$. Maximum reduction in HI was observed in IR20 (50.56\%) while minimum was observed in Vandana $(0.55 \%)$ in DS condition as compared with WW condition. Mahamaya, Sahabahagidhan and Vandana had higher GF\% (>51.80) under DS condition while, susceptible check IR20 attained lowest GF\% (32.49\%). Comparatively lower percentage reduction in GF\% was noticed in Vandana, Danteshwari and Poornima (24.25 $36.25 \%$ ) and higher percentage reduction was noticed in susceptible check IR20 (60.70\%) in DS as compared to WW condition. In case of 1000 grain weight (GW), the maximum reduction was observed in Vandana (9.69\%), 
bioRxiv preprint doi: https://doi.org/10.1101/2020.05.29.122929; this version posted June 1, 2020. The copyright holder for this preprint (which was not certified by peer review) is the author/funder. All rights reserved. No reuse allowed without permission.

229 IR20 (6.69\%) and Hazaridhan (5.19\%) while minimum reduction was recorded in Sahabhagidhan (0.68\%), 230 Samleshwari $(0.76 \%)$ and IBD-1 (1.38\%) in DS over WW condition. Minimum yield reduction in Danteswari 231 and Samaleswari may be contributed by less reduction in PN, TDM and higher GF\%.

232 
Table-3 Grain yield and yield attributes of 21 rice genotypes under well-watered (WW) and drought stress (DS) of the dry season from pooled data of 2017 and 18.

\begin{tabular}{|c|c|c|c|c|c|c|c|c|c|c|c|c|c|c|c|c|c|c|}
\hline \multirow[t]{2}{*}{$\overline{\overline{\text { SN }}}$} & \multirow[t]{2}{*}{ Genotypes } & \multicolumn{2}{|c|}{ PH(cm) } & \multicolumn{2}{|c|}{ TN/m2 } & \multicolumn{2}{|c|}{ PN/m2 } & \multicolumn{2}{|c|}{ TDM (t/ha) } & \multicolumn{2}{|c|}{ GY(t/ha) } & \multicolumn{2}{|c|}{ HI } & \multicolumn{2}{|c|}{ GF\% } & \multicolumn{2}{|c|}{$\overline{\text { GW }}$} & \multirow[t]{2}{*}{ RYR } \\
\hline & & WW & DS & WW & DS & WW & DS & WW & DS & WW & & WW & DS & WW & DS & WW & DS & \\
\hline$\overline{1}$ & DANTESHWARI & 97.83 & 84.02 & 300.81 & 263.07 & 347.99 & 320.24 & 7.97 & 6.27 & 3.29 & 2.00 & 0.413 & 0.323 & 73.81 & 50.06 & 23.19 & 22.43 & 39.11 \\
\hline 2 & MAHAMAYA & 115.22 & 102.84 & 350.21 & 296.37 & 444.00 & 329.67 & 14.02 & 8.70 & 4.50 & 2.42 & 0.322 & 0.281 & 86.60 & 53.36 & 29.96 & 28.78 & 46.37 \\
\hline 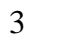 & MTU 1010 & 95.23 & 84.08 & 318.02 & 186.48 & 376.85 & 198.14 & 14.64 & 4.05 & 4.02 & & & & & & & & \\
\hline 4 & SAMLESHWARI & 107.72 & 100.54 & 291.93 & 239.76 & 357.98 & 286.94 & 12.15 & 7.73 & 3.59 & 2.05 & 0.297 & 0.266 & 76.49 & 46.86 & 21.53 & 21.37 & 42.88 \\
\hline 4 & POORNIMA & 90.82 & 84.00 & 292.49 & 253.64 & 362.97 & 279.72 & 9.14 & 5.41 & 3.25 & 1.86 & 0.356 & 0.346 & 80.28 & 51.18 & 23.29 & 22.75 & 42.67 \\
\hline 6 & IBD-1 & 101.55 & 92.53 & 321.35 & 273.62 & 435.12 & 281.94 & 12.61 & 5.86 & 4.02 & 1.69 & 0.323 & 0.291 & 89.56 & 49.36 & 22.15 & 21.85 & 58.03 \\
\hline 7 & SAFRI 17 & & & & & $\mathrm{NF}$ & $\mathrm{NF}$ & & & $\mathrm{NF}$ & $\mathrm{NF}$ & $\mathrm{NF}$ & NF & $\mathrm{NF}$ & $\mathrm{NF}$ & $\mathrm{NF}$ & $\mathrm{NF}$ & \\
\hline 8 & SWAR & 8.23 & 85.63 & 361.31 & 187.04 & 448.44 & 181.64 & 5.86 & 4.16 & 5.04 & 1.13 & 0.319 & 0.272 & 89.63 & 41.79 & 16.22 & 1 & $1 .$. \\
\hline 9 & IR64 & 9.42 & 81.31 & 361.31 & 176.49 & 447.89 & 204.24 & 13.39 & 3.87 & 5.04 & 0 & 0.378 & 97 & 86.49 & 3 & .59 & & 85.01 \\
\hline 10 & SAHA & 110.22 & 106.49 & 325.79 & 283.05 & 399.60 & 308.03 & 13.64 & 6.26 & 4.73 & 2.00 & 0.348 & 0. & 84.72 & 52.03 & 23.10 & 2 & 57.72 \\
\hline 11 & KHA & 99.58 & 87.29 & 284.72 & 222.00 & 372.96 & 268.07 & 10.75 & 4.57 & 3.67 & 1.35 & 0.343 & 0.296 & 79.47 & 50.17 & 19.89 & 1 & 63.14 \\
\hline 12 & KAL & 03.94 & 93.77 & 236.43 & 209.79 & & & 8.13 & 4.61 & 2.76 & 1.53 & 0.340 & & 77.71 & 46 & 21.82 & 2 & 44.48 \\
\hline 13 & VANI & 06.11 & 94.52 & 240.32 & 224.78 & 355.20 & 288.05 & 9.73 & 5.45 & 3.22 & 1.79 & 0.330 & 0.329 & 68.38 & 51.80 & 23.33 & 2 & 44.32 \\
\hline 14 & SAT & 103.42 & 96.23 & 266.96 & 192.03 & 335.22 & 277.50 & 9.47 & 4.59 & 3.33 & 1.47 & 0.354 & 0. & 79.04 & 43 & 23.85 & 2 & 55.96 \\
\hline 15 & AN & 92.17 & 83.91 & 261.96 & 211.46 & 306.92 & 264.18 & 9.47 & 5.27 & 3.20 & 1.48 & 0.341 & & 79.69 & 45 & 23.78 & & 53.76 \\
\hline 16 & CR DH & 105.22 & 95.91 & 296.37 & 228.66 & 361.31 & 290.82 & 12.19 & 4.80 & 3.58 & 1.28 & 0.295 & 0. & 80.59 & 46.22 & 18.65 & 17 & 64.20 \\
\hline 17 & $\mathrm{~N}$ & 90.84 & 83.46 & 309.69 & 223 & & & 10.45 & 3.99 & 4.00 & 1.45 & 0 & 0 & 88.26 & 45.23 & 20.67 & & 63.82 \\
\hline 18 & IR & 4.51 & 74.06 & 326.90 & 172 & 397.38 & 11 & 12.98 & 3.60 & 4.79 & 0.66 & 0.372 & & 82.66 & 32.49 & 19.97 & & 86.28 \\
\hline 19 & VIRENDI & 105.27 & 92.76 & 305.81 & 201.47 & 395.72 & 223.67 & 10.77 & 4.26 & 4.48 & 1.10 & 0.417 & 0.257 & 81.18 & 48.37 & 23.83 & 23.27 & 75.49 \\
\hline 20 & & 93.50 & 520 & & & & & 9.54 & 5.12 & 3.38 & & & & 70.66 & & & & 6699 \\
\hline \multirow[t]{3}{*}{21} & HAZARIDHAN & 92.87 & 83.70 & 332.45 & 229.22 & 420.14 & 260.30 & 14.08 & 5.84 & 4.39 & 1.62 & 0.313 & 0.277 & 87.69 & 49.41 & 21.73 & 20.61 & 63.14 \\
\hline & Mean & 101.68 & 89.62 & 301.86 & 224.22 & 376.87 & 253.73 & 11.55 & 5.22 & 3.91 & 1.48 & 0.34 & 0.28 & 81.46 & 46.17 & 22.47 & 21.71 & 0.48 \\
\hline & & 1.61 & 1.83 & 8.28 & 70 & 10.43 & 11.64 & 0.52 & 0.29 & 0.15 & 0.1 & 0.01 & 0.01 & 1.36 & 1.24 & 0.62 & 066 & \\
\hline \multirow{2}{*}{\multicolumn{2}{|c|}{$\%$ increase/decrease }} & \multicolumn{2}{|c|}{-11.87} & \multicolumn{2}{|c|}{-25.72} & & \multicolumn{2}{|l|}{-54} & -62 . & & \multicolumn{2}{|c|}{-18.15} & & 3.32 & \multicolumn{2}{|c|}{-3.39} & \\
\hline \multirow{2}{*}{\multicolumn{2}{|c|}{$\mathbf{L S D}_{0.05}(\mathbf{G})$}} & \multirow{2}{*}{\multicolumn{2}{|c|}{$\begin{array}{l}1.37 \\
\mathbf{0 . 4 3}\end{array}$}} & \multirow{2}{*}{\multicolumn{2}{|c|}{$\begin{array}{l}7.46 \\
2.36\end{array}$}} & \multirow{2}{*}{\multicolumn{2}{|c|}{$\begin{array}{l}7.53 \\
2.38\end{array}$}} & & & & \multicolumn{2}{|c|}{0.017} & 2.6 & 0 & & & \\
\hline & & & & & & & & 0.2 & & 0.0 & & & 005 & 0.8 & dJ & 0.5 & & \\
\hline LSI & .05 (GXT) & 1. & 94 & & .54 & 10 & .65 & 0.9 & & 0.2 & & & 025 & 3.7 & 72 & 2.2 & 27 & \\
\hline
\end{tabular}

DFF- Days to 50\% flowering, PH- Plant height, TN- Tiller numbers, PN-Panicle numbers, TDM-Total dry matter, GY- Grain yield, HI- Harvest index, GF\%- Grain filling percentage, GW- 1000 grain test weight, RYR - Relative yield reduction 


\section{Correlation between grain yield and yield related traits}

Under DS condition, DFF showed negative correlation with HI, PH, TN, GY, PN, FT\% and GW but none of the correlation was significant except with $\mathrm{HI}(\mathrm{p}<0.01)$. GY was positively associated with all the traits except DFF but showed a non-significant positive correlation with GW. TDM had a highly significant and positive correlation with GY (p<0.01), PN ( $<<0.01)$, FT\% $(\mathrm{p}<0.01)$, TN $(\mathrm{p}<0.01)$ and PH $(\mathrm{p}<0.01)$. Similarly, GW showed non-significant correlation with all the traits except PN $(\mathrm{p}<0.05)$. Grain yield was significantly $(\mathrm{P}<0.01)$ correlated with DFF under WW condition and contributes $39.3 \%$ for grain yield, while it showed a non-significant positive correlation $(\mathrm{p}<0.2, \mathrm{r}=0.237)$ under DS condition and contributes only $5.60 \%$ for grain yield. There was a positive significant correlation between grain yield and plant height $(\mathrm{p}<0.1)$ in WW condition while under DS condition, grain yield and plant height exhibited significant positive correlation $(\mathrm{p}<0.001)$. The tiller number, panicle number, total dry matter and grain filling percentage exhibited positively significant ( $p$ $<0.001$ ) correlation with grain yield both under WW and DS conditions (Table 4).

Table - 4 Correlation matrix of yield traits (pooled) under water stress condition

\begin{tabular}{|c|c|c|c|c|c|c|c|c|c|}
\hline & DFF & $\mathbf{P H}$ & TN & TDM & GY & HI & PN & $\begin{array}{c}\text { GF } \\
\%\end{array}$ & GW \\
\hline DFF & 1 & & & & & & & & \\
\hline PH & -0.073 & 1 & & & & & & & \\
\hline $\mathbf{T N}$ & -0.117 & $0.598^{* *}$ & 1 & & & & & & \\
\hline TDM & 0.194 & $0.639^{* *}$ & $0.771^{* *}$ & 1 & & & & & \\
\hline GY & -0.169 & $0.659^{* *}$ & $\mathbf{0 . 8 8 8}^{* *}$ & $0.829^{* *}$ & 1 & & & & \\
\hline HI & $\begin{array}{l}- \\
0.617^{* *}\end{array}$ & 0.275 & $0.450^{*}$ & 0.054 & $0.588^{* * *}$ & 1 & & & \\
\hline PN & -0.425 & $0.633^{* *}$ & $0^{7.798}{ }^{* *}$ & $0.595^{* *}$ & $\mathbf{0 . 8 3 8}^{* *}$ & $0.609^{* *}$ & 1 & & \\
\hline GF\% & -0.409 & $0.609^{* *}$ & $0.825^{* *}$ & $0.636^{* * *}$ & $0.841^{* *}$ & $0.614^{* *}$ & $0.821^{* *}$ & 1 & \\
\hline GW & -0.225 & 0.307 & 0.411 & 0.432 & 0.401 & 0.024 & $0.446^{*}$ & 0.312 & 1 \\
\hline $\begin{array}{l}\text { DFF- } \\
\text { Grain } \\
\text { 1000g } \\
\text { 0.01 le }\end{array}$ & $\begin{array}{l}\text { \% flow } \\
\text { Harves } \\
\text { veight. }\end{array}$ & $\begin{array}{l}\text { ing, PH- } \\
\text { ndex, I } \\
\text { Correla }\end{array}$ & $\begin{array}{l}\text { lant hi } \\
\text { - Pani } \\
\text { on is si }\end{array}$ & $\begin{array}{l}\text { ht, TN- } \\
\text { numbe } \\
\text { ficant a }\end{array}$ & $\begin{array}{l}\text { s numb } \\
\Gamma \%-\mathrm{Sp} \\
0.05 \mathrm{lev}\end{array}$ & $\begin{array}{l}\text { TDM- T } \\
\text { *. Corrtilit } \\
\text {. Corre }\end{array}$ & $\begin{array}{l}\text { tal dry } \\
\text { percen } \\
\text { ation is }\end{array}$ & $\begin{array}{l}\text {, GY } \\
\text { Cant at }\end{array}$ & \\
\hline
\end{tabular}

The Pearson correlation of the grain yield showed less positive $(\mathrm{p}>0.2)$ correlation with harvest index in WW condition and $\mathrm{HI}$ contributes $0.4 \%$, while it was significantly positive $(\mathrm{p}<0.001)$ correlation between grain yield with harvest index under DS condition and HI contributes $66.40 \%$ to grain yield. There was a less positive $(\mathrm{p}>0.1)$ correlation of GW with grain yield and GW contributes only $1.61 \%$ to the grain yield under WW condition, while under DS condition, positive $(\mathrm{p}<0.05)$ correlation among GW and GY indicate GW contributes $17.58 \%$ to GY. Under WW condition TN, PN, TDM and GF\% contributes 80.90\%, 75.30\%, 69.50\% and $50.10 \%$ whereas under DS condition these parameters contributes $78.70 \%, 75.70 \%, 77.90 \%$ and $70.30 \%$ respectively towards grain yield (Fig 8).

\section{Agglomerative Cluster analysis:}

Agglomerative Cluster analysis based on pearson correlation coefficient and unweight pair group analysis by considering grain yield and yield related traits, classified 20 genotypes (except Safri 17) into two main clusters I and II, at similarity coefficient of -0.635 . The cluster I divided into 2 sub clusters: IA and IB, at 
similarity coefficient of 0.565 and the sub cluster IA and IB consist of 4 genotypes each. The cluster II divided into 2 sub clusters: IIA and IIB, at similarity coefficient of 0.365 . The sub cluster IIA included 7 genotypes, and cluster IIB consist of 5 genotypes (Fig 9). This pattern of clustering explained the existence of a significant amount of diversity among the genotypes.

Cluster IA included all the drought sensitive genotypes (Swarna, IR20, MTU 1010 and IR20) having longer DFF, and lowest tillers number, panicles number, total dry matters, grain yield, harvest index and grain filling percentage. Cluster IB consisted of genotypes (N22, Kalinga III, Virendra and Vanaprabha) having moderate to lower tiller number, panicles number, total dry matters and grain filling percentage. Clustered IIA is having genotypes (Hazaridhan, Samleshwari, Danteshwari, Mahamaya, Sahabhagidhan, Poornima and IBD-1) with high tiller number, panicle number, total dry matter, grain yield and grain filling percentage indicating drought tolerance and cluster IIB is characterized by the genotypes (Satyabhama, Anjali, Khandagiri,Vandana and CR Dhan 40) having moderate to lower value of DFF and higher to moderate value of plant height, panicles number and harvest index (Fig 9).

\section{Discussion:}

In the present study attempt has been made to identify suitable genotype for rainfed upland condition of eastern India that mostly suffers from drought. Under drought stress condition, grain yield is determined by its phenological, physiological and yield traits (Barnaby et al 2019In the present study stress was imposed both at vegetative and reproductive stage. Under drought, mean RWC decreased to $65.9 \%$ and LWP reached to -3.65 $\mathrm{MPa}$. According to previous studies, LWP below -1.7 MPa affect plant growth (Santos et al 2018) which is supporting our results of decrease in plant height by $11.87 \%$ during stress period. Soil moisture tension during the stress was $-47.83 \mathrm{kPa}$ and $-54.55 \mathrm{kPa}$ in 2017 and 2018. Torres et al. (2018) reported similar results of occurring moderate to severe stress when soil moisture tension drops below $-50 \mathrm{kPa}$. Drought stress at vegetative stage reduces water content and lower leaf water potential, leading to reduce turgor, stomatal conductance, and photosynthesis, and ultimately reduce grain yield (Akbarian et al., 2011; Amini et al., 2014). In our study, Mahamaya, Samaleswari, Poornima, IBD-1, Safri 17, Sahabhagidhan and N22 appears to be drought tolerant to the vegetative stage drought with SES drought score ' 1 ' at the end of the stress period and had early recovery after the stress was relieved. The identified genotypes also had high RWC (>70\%) and LWP (>3.50 MPa) compared to susceptible genotypes like IR 20, IR 64 and MTU 1010 (Kumar et al., 2014). Drought score is used to measure the tolerance toward drought stress condition and reflects the extent of correlation of the plant tissue dehydration with its RWC (Ingram and Bartels, 1996; Cabuslay et al., 1999; 2002). The ability of the plant to recover after the drought relief is considered more crucial than drought tolerance (Fang and Xiong, 2015; Chen et al., 2016) which is important selection criterion for selecting drought tolerant genotypes. The seven identified genotypes had low drought score with higher recovery rate justifies their tolerance towards drought.

Though the genotypes have vegetative stage drought tolerance, they may not perform well in terms of grain yield production under drought (Swain et al., 2017). For effective screening, drought stress was imposed during flowering stage (Pantuwan et al., 2002) and to synchronize flowering staggered showing was adopted (Garrity and O'Toole, 1994). Out of seven genotypes showing tolerance at vegetative stage, only four genotypes 
(Mahamaya, Samleshswari, Sahabhagidhan and Danteswari) showed tolerance to reproductive stage drought stress. In this experiment, drought stress was severe enough to reduce grain yield to a greater extent. The result showed genotypic variation in grain yield between drought tolerant sensitive genotypes under a specific type of drought (Torres et al., 2018). Under drought stress, grain yield is one of the important selection criterions and it is determined by several phenological and yield attributes such as flowering duration, plant height, tiller numbers, panicle numbers, total dry matter, harvest index, grain filling percentage and 1000 grain weight. The most important trait contributing to drought tolerance in these four identified genotypes was higher leaf water potential that caused dehydration avoidance lead to higher biomass than IR 20 and IR 64 under stress. Due to high biomass, these four genotypes had better abilities to maintain a high growth rate under stress with less reduced PH, PN, and GF\% under reproductive stage stress. According to Blum (2005), some genotypes have the mechanism of maintaining high plant water status despite of having more biomass and plant height due to less water using ability and more water absorbing capacity. This mechanism provided a good explanation for the significant positive correlation between TDM to GY and TDM to GF. From the above, the conclusion can be made that in eastern Asia, rainfed lowland rice is mostly a drought avoider, and produce higher grain yield under drought due to the ability of maintaining plant water status around flowering and grain filling (Fukai et al., 2009). Another mechanism that contributed to drought tolerance could be efficient partitioning partially resulting from shorter plant and less delay in DFF that resulted in higher GW and GF\% under drought (Guan et al, 2010). Previous studies reported that increase in HI under drought is of critical importance for drought tolerance (grain yield) under terminal drought stress (Monneveux et al., 2008). But no such phenomenon was observed here, but a strong positive correlation $(\mathrm{p}<0.01)$ existed between HI with TDM and GY which indicates higher remobilization of assimilates to the grains from stems and leaves under drought (Kumar et al., 2006).

Drought escape or accelerated heading under drought, might contributed to drought tolerance. Our results showed that, N22 and Anjali flowered 5-7 days earlier compared to WW. Early flowering could partly responsible for the improved GF\% and GW under DS because early flowering would allow plants to escape from severe terminal stress in rice (Xu et al., 2005). This drought escape by drought-induced accelerated heading in N22 and Anjali was expressed at the vegetative stage drought and had grain yield of $>1.4$ t/ha. It is important to mention here that the above discussed mechanisms function together and affected the same set of drought tolerance related traits but appeared to vary considerably depending on specific scenarios of drought stress. In our study significant variation in drought tolerance (in terms of grain yield) observed suggest that, for evaluation of genotypes should be performed under the type(s) of stress similar to the target environment. In the present study, VS had greater effects on traits like PH, PN and biomass (source supply), whereas RS more severely affected traits like GF\% and GW that determine the sink size and partitioning. So, genotypes targeting for rainfed lowland where terminal drought is more frequent, should be evaluated under a severe RS. While selecting genotypes for rainfed upand, evaluation under both severe VS and RS would be required. Selection for grain yield under reproductive stress was practised due to the stress has much greater effect on the grain yield of rice (Serraj et al., 2009). However, visual selection for a large sink size under favourable conditions and higher source capacity (seedling vigour and tiller number) under VS and greater fertility under RS may help during large population screening (Blum, 2004).

\section{Conclusions}


The present study identified some genotypes (Sahabhagidhan, Poornima, Vandana, and N22) that were tolerant to both vegetative as well as reproductive stage drought stress. Combining tolerance of both vegetative as well as reproductive-stage drought could be accomplished by performing separate trials for both the stresses that will help in the development of improved varieties with tolerance to multiple growth stages and help to maintain stable grain yield in rainfed ecosystem umder the prevailing unpredictable climatic situations.

\section{REFERENCES}

Acuña, T. L. B., Lafitte, H. R., \& Wade, L. J. (2008). Genotype $\times$ environment interactions for grain yield of upland rice backcross lines in diverse hydrological environments. Field Crops Research, 108, 117-125. https://doi.org/10.1016/j.fcr.2008.04.003.

Akbarian, A., Arzani, A., Salehi, M., \& Salehi, M. (2011). Evaluation of triticale genotypes for terminal drought tolerance using physiological traits. Indian Journal of Agricultural Sciences, 81 (12), 1110-1115,

Amini, H., Arzani, A., \& Karami, M. (2014). Effect of water deficiency on seed quality and physiological traits of different safflower genotypes. Turkish Journal of Biology, 38, 271-282. https://doi.org/10.3906/biy$\underline{1308-22}$.

Bajji, M., Lutts, S., \& Kinet, J. M. (2001). Water deficit effects on solute contribution to osmotic adjustment as a function of leaf ageing in three durum wheat (Triticum durum Desf.) cultivars performing differently in arid conditions. Plant Science, 160(4), 669-681. https://doi.org/10.1016/S0168-9452(00)00443-X .

Barnaby, J. Y., Rohila, J. S., Henry, C. G., Sicher, R. C., Reddy, V. R., \& McClung, A. M. (2019). Physiological and metabolic responses of rice to reduced soil moisture: Relationship ofwater stress tolerance and grain production. International Journal of Molecular Sciences, 20(8), 1-20. https://doi.org/10.3390/ijms20081846 .

Blum, A. (2005). Drought resistance, water-use efficiency, and yield potential - Are they compatible, dissonant, or mutually exclusive? In Australian Journal of Agricultural Research, 56, 1159-1168. https://doi.org/10.1071/AR05069.

Cabuslay, G. S., Ito, O., \& Alejar, A. A. (2002). Physiological evaluation of responses of rice (Oryza sativa L.) to water deficit. Plant Science, 163, 815-827. https://doi.org/10.1016/S0168-9452(02)00217-0.

Cabuslay, G., Ito, O., \& Alejar, A. (1999). Genotypic differences in physiological responses to water deficit in rice. In Osamu Ito, J. C. O'Toole, Bill Hardy, Genetic improvement of rice for water-limited environments (pp.99-116). Philippines: IRRI..

Chen, D., Wang, S., Cao, B., Cao, D., Leng, G., Li, H., et al. (2016). Genotypic variation in growth and physiological response to drought stress and re-watering reveals the critical role of recovery in drought adaptation in maize seedlings. Frontiers in Plant Science, 6(1241), 1-15. https://doi.org/10.3389/fpls.2015.01241 .

dos Santos, C. L., Reis, A. F. de B., Mazzafera, P., \& Favarin, J. L. (2018). Determination of the water potential threshold at which rice growth is impacted. Plants, 48,1-8. https://doi.org/10.3390/plants7030048 .

EKANAYAKE, I. J., DATTA, S. K. DE, \& STEPONKUS, P. L. (1989). Spikelet Sterility and Flowering Response of Rice to Water Stress at Anthesis. Annals of Botany, 63(2), 257-264. https://doi.org/10.1093/oxfordjournals.aob.a087740 .

Fabre, D., Siband, P., \& Dingkuhn, M. (2005). Characterizing stress effects on rice grain development and 
filling using grain weight and size distribution. Field Crops Research, 92, 11-16. https://doi.org/10.1016/i.fcr.2004.07.024.

Fang, Y., \& Xiong, L. (2015). General mechanisms of drought response and their application in drought resistance improvement in plants. Cellular and Molecular Life Sciences., 72, 673-689. https://doi.org/10.1007/s00018-014-1767-0 .

Fen, L. L., Ismail, M. R., Zulkarami, B., Rahman, M. S. A., \& Islam, M. R. (2015). Physiological and molecular characterization of drought responses and screening of drought tolerant rice varieties. Bioscience Journal, 31(3), 709-718. https://doi.org/10.14393/BJ-v31n3a2015-23461

Fukai, S., Pantuwan, G., Jongdee, B., \& Cooper, M. (1999). Screening for drought resistance in rainfed lowland rice. Field Crops Research, 64, 61-74. https://doi.org/10.1016/S0378-4290(99)00051-9 .

Fukai, Shu and Basnayake, Jayampathi W.M. (2008). Drought resistance characters and variety development for rainfed lowland rice in Southeast Asia. In R. Serraj, J. Bennett and B. Hardy, Drought Frontiers in Rice: Crop Improvement for Increased Rainfed Production (pp. 7589). Manila, Philippines: World Scientific.

Garrity, D. P., \& O'Toole, J. C. (1994). Screening rice for drought resistance at the reproductive phase. Field Crops Research, 39, 99-110. https://doi.org/10.1016/0378-4290(94)90012-4 .

Guan, Y. S., Serraj, R., Liu, S. H., Xu, J. L., Ali, J., Wang, W. S., et al. (2010). Simultaneously improving yield under drought stress and non-stress conditions: A case study of rice (Oryza sativa L.). Journal of Experimental Botany, 61(15), 4145-4156. https://doi.org/10.1093/jxb/erq212 .

Gutierrez, M., Reynolds, M. P., \& Klatt, A. R. (2010). Association of water spectral indices with plant and soil water relations in contrasting wheat genotypes. Journal of Experimental Botany, 61 (12), 3291-3303. https://dx.doi.org/10.1093\%2Fjxb\%2Ferq156

Hassanzadeh, M., Ebadi, A., Panahyan-e-Kivi, M., Eshghi, A. G., Jamaati-e-Somarin, S., Saeidi, M., \& Zabihie-Mahmoodabad, R. (2009). Evaluation of Drought Stress on Relative Water Content and Chlorophyll Content of Sesame (Sesamum indicum L.) Genotypes at Early Flowering Stage. Research Journal of Environmental Sciences, 3(3), 345-350. https://doi.org/10.3923/rjes.2009.345.350.

Ingram, J., \& Bartels, D. (1996). The molecular basis of dehydration tolerance in plants. Annual Review of Plant Physiology and Plant Molecular Biology, 47, 377-403. https://doi.org/10.1146/annurev.arplant.47.1.377.

International Rice Research Institute (IRRI). 2002. Standard Evaluation System for Rice. Los Banos, the Philippines:International Rice Research Institute.

IRRI (1996). Facts about Co-operation: India and IRRI, No. 9, IRRI, Manila, Philippines.

IRRI (2014). Standard Evaluation System for Rice. 5th edn. Los Banos, the Philippines: International Rice Research Institute.

Keelery, S. (2020). Area of cultivation for rice in India 2013-2018. Statista, https://www.statista.com/statistics/765691/india-area-of-cultivation-for-rice/

Kumar, R., Sarawgi, A. K., Ramos, C., Amarante, S. T., Ismail, A. M., \& Wade, L. J. (2006). Partitioning of dry matter during drought stress in rainfed lowland rice. Field Crops Research, 98(1), 1-11. https://doi.org/10.1016/j.fcr.2005.09.015.

Kumar, S., Dwivedi, S. K., Singh, S. S., Jha, S. K., S, L., Elanchezhian, R., et al. (2014). Identification of 
drought tolerant rice genotypes by analysing drought tolerance indices and morpho-physiological traits. Sabrao Journal of Breeding and Genetics, 46(2), 217-230.

Lal, B., Gautam, P., Panda, B. B., Raja, R., Singh, T., Tripathi, R., et al. (2017). Crop and varietal diversification of rainfed rice based cropping systems for higher productivity and profitability in Eastern India. PLoS ONE, 12(4), e0175709. https://doi.org/10.1371/journal.pone.0175709 .

Liu, J. X., Liao, D. Q., Oane, R., Estenor, L., Yang, X. E., Li, Z. C., \& Bennett, J. (2006). Genetic variation in the sensitivity of anther dehiscence to drought stress in rice. Field Crops Research, 97, 87-100. https://doi.org/10.1016/j.fcr.2005.08.019 .

Manickavelu, A., Nadarajan, N., Ganesh, S. K., Gnanamalar, R. P., \& Chandra Babu, R. (2006). Drought tolerance in rice: Morphological and molecular genetic consideration. Plant Growth Regulation, 50, 121138. https://doi.org/10.1007/s10725-006-9109-3.

MARDI (Malaysian Agricultural Research and Development Institute) (2009) Paddy Grow: Sustainable Rice Cultivation Technology Manual. MARDI Press. (in Malay).

Mishra, B.K (2005) Histochemical studies on accumulation and remobilization of starch at flowering stage in upland rices. M.Sc. Thesis, Narendra Deva University of Agriculture of Agriculture and Technology, Narendra Nagar, Kumarganj, Faizabad, U.P., India.

Mitchell, J. H., Siamhan, D., Wamala, M. H., Risimeri, J. B., Chinyamakobvu, E., Henderson, S. A., \& Fukai, S. (1998). The use of seedling leaf death score for evaluation of drought resistance of rice. Field Crops Research, 55(1-2), 129-139. https://doi.org/10.1016/S0378-4290(97)00074-9.

Monneveux, P., Sanchez, C., \& Tiessen, A. (2008). Future progress in drought tolerance in maize needs new secondary traits and cross combinations. Journal of Agricultural Science, 146, 287-300. https://doi.org/10.1017/S0021859608007818 .

Nour, M.A. Abd-El-Wahab, A.E. Mahrous, F. (1995). Effect of water stress at different growth stages on rice yield and contributing variables. Journal of Agricultural Sciences, Mansoura Univ. (Egypt), 19(2), 403412 .

Pantuwan, G., Fukai, S., Cooper, M., Rajatasereekul, S., \& O’Toole, J. . (2002a). Yield response of rice (Oryza sativa L.) genotypes to drought under rainfed lowland. Field Crops Research, 73: 181-200. https://doi.org/10.1016/S0378-4290(01)00194-0 .

Pantuwan, G., Fukai, S., Cooper, M., Rajatasereekul, S., \& O’Toole, J. C. (2002b). Yield response of rice (Oryza sativa L.) genotypes to drought under rainfed lowlands 2. Selection of drought resistant genotypes. Field Crops Research, 73, 169-189. https://doi.org/10.1016/S0378-4290(01)00195-2 .

Pathak, H., Samal, P., and Shahid, M. (2018). Revitalizing Rice-Systems for Enhancing Productivity, Profitability and Climate Resilience. In H. Pathak, A.K. Nayak, M. Jena, O. N. Singh, P. Samal and S. G. Sharma. Rice Research for Enhancing Productivity, Profitability and Climate Resilience (pp. 1-17). Cuttack: Director, ICAR-National Rice Research Institute.

Ray, D. K., Gerber, J. S., Macdonald, G. K., \& West, P. C. (2015). Climate variation explains a third of global crop yield variability. Nature Communications, 1-9. https://doi.org/10.1038/ncomms6989 .

Schonfeld, M. A., Johnson, R. C., Carver, B. F., and Mornhinweg, D. W. 1988. Water Relations in Winter Wheat as Drought Resistance Indicators. Crop Science, 28, 526-531. https://doi.org/10.2135/cropsci1988.0011183X002800030021x . 
Serraj, R., Kumar, A., McNally, K. L., Slamet-Loedin, I., Bruskiewich, R., Mauleon, R., et al. (2009). Chapter 2 Improvement of Drought Resistance in Rice. Advances in Agronomy, 103, 42-67. https://doi.org/10.1016/S0065-2113(09)03002-8 .

Silva, E. N., Ferreira-Silva, S. L., Viégas, R. A., \& Silveira, J. A. G. (2010). The role of organic and inorganic solutes in the osmotic adjustment of drought-stressed Jatropha curcas plants. Environmental and Experimental Botany, 69, 279-285 https://doi.org/10.1016/j.envexpbot.2010.05.001.

Silva, M. D. A., Jifon, J. L., Da Silva, J. A. G., \& Sharma, V. (2007). Use of physiological parameters as fast tools to screen for drought tolerance in sugarcane. Brazilian Journal of Plant Physiology, 19(3),193201.https://doi.org/10.1590/S1677-04202007000300003.

Silvestre, W. V. D., Silva, P. A., Palheta, L. F., de Oliveira Neto, C. F., de Melo Souza, R. O. R., FestucciBuselli, R. A., \& Pinheiro, H. A. (2017). Differential tolerance to water deficit in two açaí (Euterpe oleracea Mart.) plant materials. Acta Physiologiae Plantarum, 39 (4), 1-10. https://doi.org/10.1007/s11738-016-2301-9.

Singh, B., Reddy, K. R., Redoña, E. D., \& Walker, T. (2017). Screening of Rice Cultivars for MorphoPhysiological Responses to Early-Season Soil Moisture Stress. Rice Science, 24(6), 322-335. https://doi.org/10.1016/j.rsci.2017.10.001 .

Swain, P., Raman, A., Singh, S. P., \& Kumar, A. (2017). Breeding drought tolerant rice for shallow rainfed ecosystem of eastern India. Field Crops Research, 209(March), 168-178. https://doi.org/10.1016/j.fcr.2017.05.007.

Torres, R. O., \& Henry, A. (2018). Yield stability of selected rice breeding lines and donors across conditions of mild to moderately severe drought stress. Field Crops Research, 220, 37-45. https://doi.org/10.1016/j.fcr.2016.09.011 .

Turner, N. C. 1988. Measurement of plant water status by the pressure chamber technique. Irrigation Science, 9(4), 289-308. https://doi.org/10.1007/BF00296704 .

Wei, S., Hu, W., Deng, X., Zhang, Y., Liu, X., Zhao, X., et al. (2014). A rice calcium-dependent protein kinase OsCPK9 positively regulates drought stress tolerance and spikelet fertility. BMC Plant Biology, 14(133), 1-13. https://doi.org/10.1186/1471-2229-14-133 .

Xu, J. L., Lafitte, H. R., Gao, Y. M., Fu, B. Y., Torres, R., \& Li, Z. K. (2005). QTLs for drought escape and tolerance identified in a set of random introgression lines of rice. Theoretical and Applied Genetics, 111, 1642-1650. https://doi.org/10.1007/s00122-005-0099-8 .

Yoshida, S., Satake T., Mackill, D., 1981. High temperature stress in rice. IRRI Research Paper Series No. 67 , 1-15.

Zhang, J., Zhang, S., Cheng, M., Jiang, H., Zhang, X., Peng, C., et al. (2018). Effect of Drought on Agronomic Traits of Rice and Wheat: A Meta-Analysis. International Journal of Environmental Research and Public Health, 15( 839), 1-14. https://doi.org/10.3390/ijerph15050839 .

Zhang, S. W., Li, C. H., Cao, J., Zhang, Y. C., Zhang, S. Q., Xia, Y. F., et al. (2009). Altered architecture and enhanced drought tolerance in rice via the down-regulation of Indole-3-acetic acid by TLD1/OsGH3.13 activation. Plant Physiology, 151(4), 1889-1901. https://doi.org/10.1104/pp.109.146803 .

Zhou, J., Wang, X., Jiao, Y., Qin, Y., Liu, X., He, K., et al. (2007). Global genome expression analysis of rice in response to drought and high-salinity stresses in shoot, flag leaf, and panicle. Plant Molecular Biology, 63, 591-608. https://dx.doi.org/10.1007\%2Fs11103-006-9111-1 . 
bioRxiv preprint doi: https://doi.org/10.1101/2020.05.29.122929; this version posted June 1, 2020. The copyright holder for this preprint (which was not certified by peer review) is the author/funder. All rights reserved. No reuse allowed without permission.

Zhu, J. (2002). Salt and Drought Stress Signal Transduction in Plants. Annu Rev Plant Biol., 53, $247-273$. https://doi.org/10.1146/annurev.arplant.53.091401.143329. 


\section{Figure Legends}

Fig 1 Meteorological data depicting maximum, minimum temperature $\left({ }^{\circ} \mathrm{C}\right)$ and rainfall $(\mathrm{mm})$ pattern during crop growth period of dry seasons 2017. DAG- days after Germination.

Fig 2 Meteorological data depicting maximum, minimum temperature and rainfall pattern during crop growth period of dry seasons 2018. DAG- days after Germination.

Fig 3 Soil moisture content (SMC \%), soil matric potential (SMP -kPa) and water table depth (cm) during the vegetative stage drought stress period in dry season 2017 and 2018.

Fig 4 Soil moisture content (SMC \%), soil matric potential (SMP -kPa) and water table depth (cm) during the reproductive stage drought stress period in dry season 2017 and 2018. DAG: days after germination.

Fig 5 Pooled data of Leaf Water Potential (MPa) under well-watered and drought stress conditions of 21 genotypes

Fig 6 Pooled data of leaf relative water content (RWC \%) under well-watered and drought stress conditions of 21 genotypes

Fig 7 Pooled data of days to 50\% flowering (DFF) data under well-watered and drought stress conditions of 20 genotypes

Fig 8 Correlation among the grain yield and yield related traits.

Fig.9 Dendrogram showing relationship among the 20 rice genotypes as revealed by Pearson correlation coefficient and Unweight pair group analysis based different yield traits. 


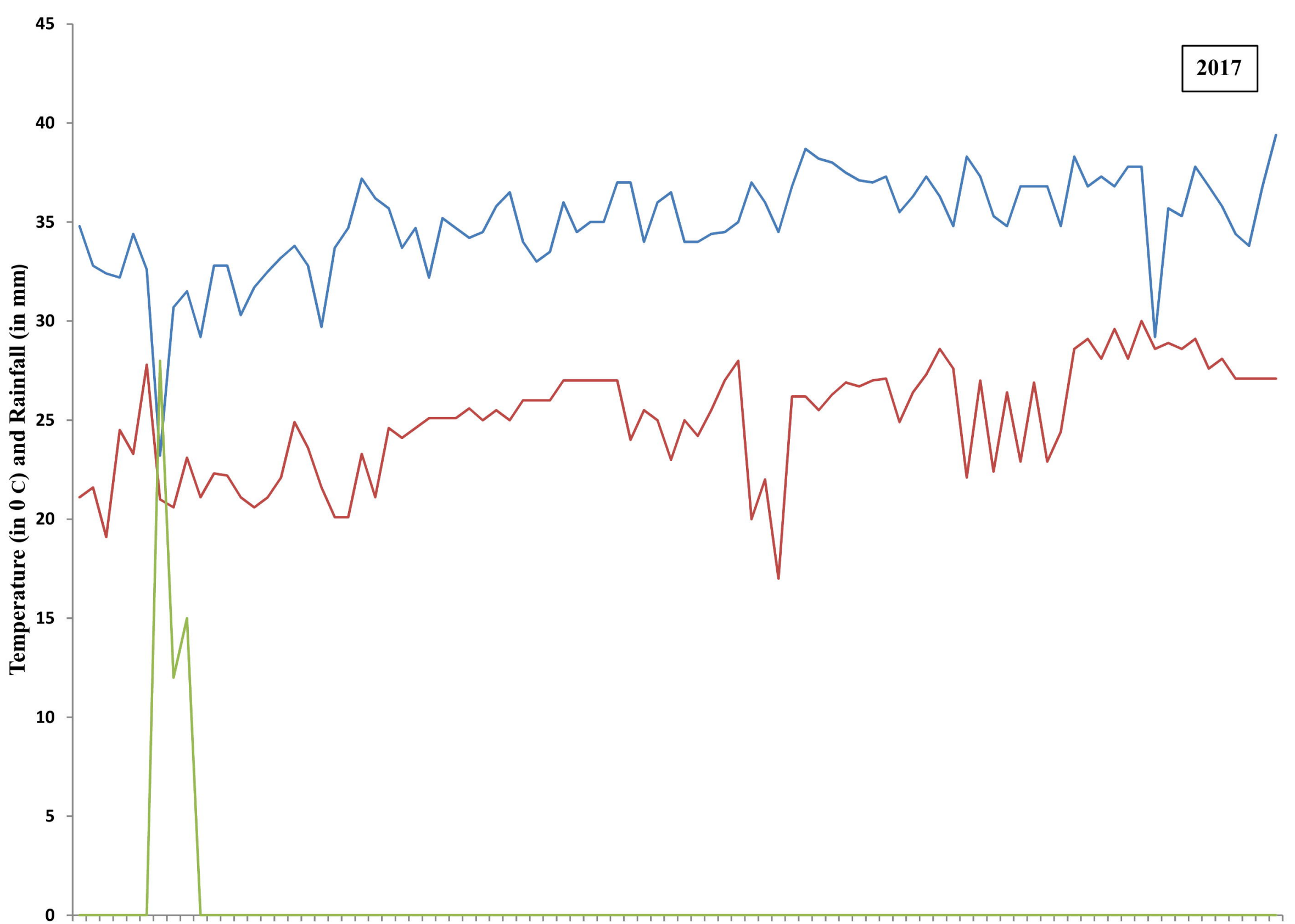

30DAG 35DAG 40DAG 45DAG 50DAG 55DAG 60DAG 65DAG 70DAG 75DAG 80DAG 85DAG 90DAG 95DAG 100DAG 105DAG 110DAG115DAG DAG: DAYS AFTER GERMINATION 


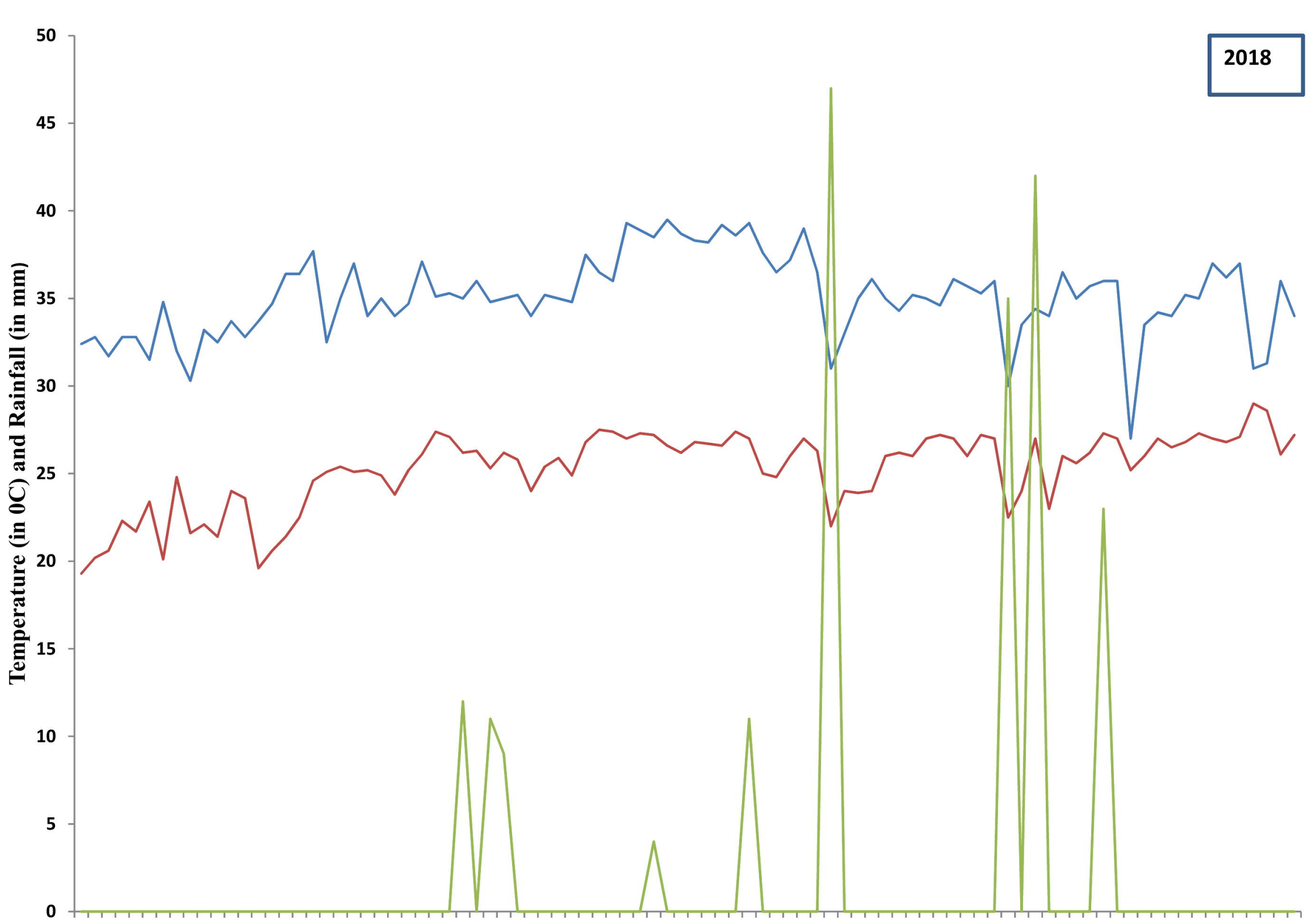

30DAG 35DAG 40DAG 45DAG 50DAG 55DAG 60DAG 65DAG 70DAG 75DAG 80DAG 85DAG 90DAG 95DAG 100DAG105DAG110DAG115DAG DAG: DAYS AFTER GERMINATION 


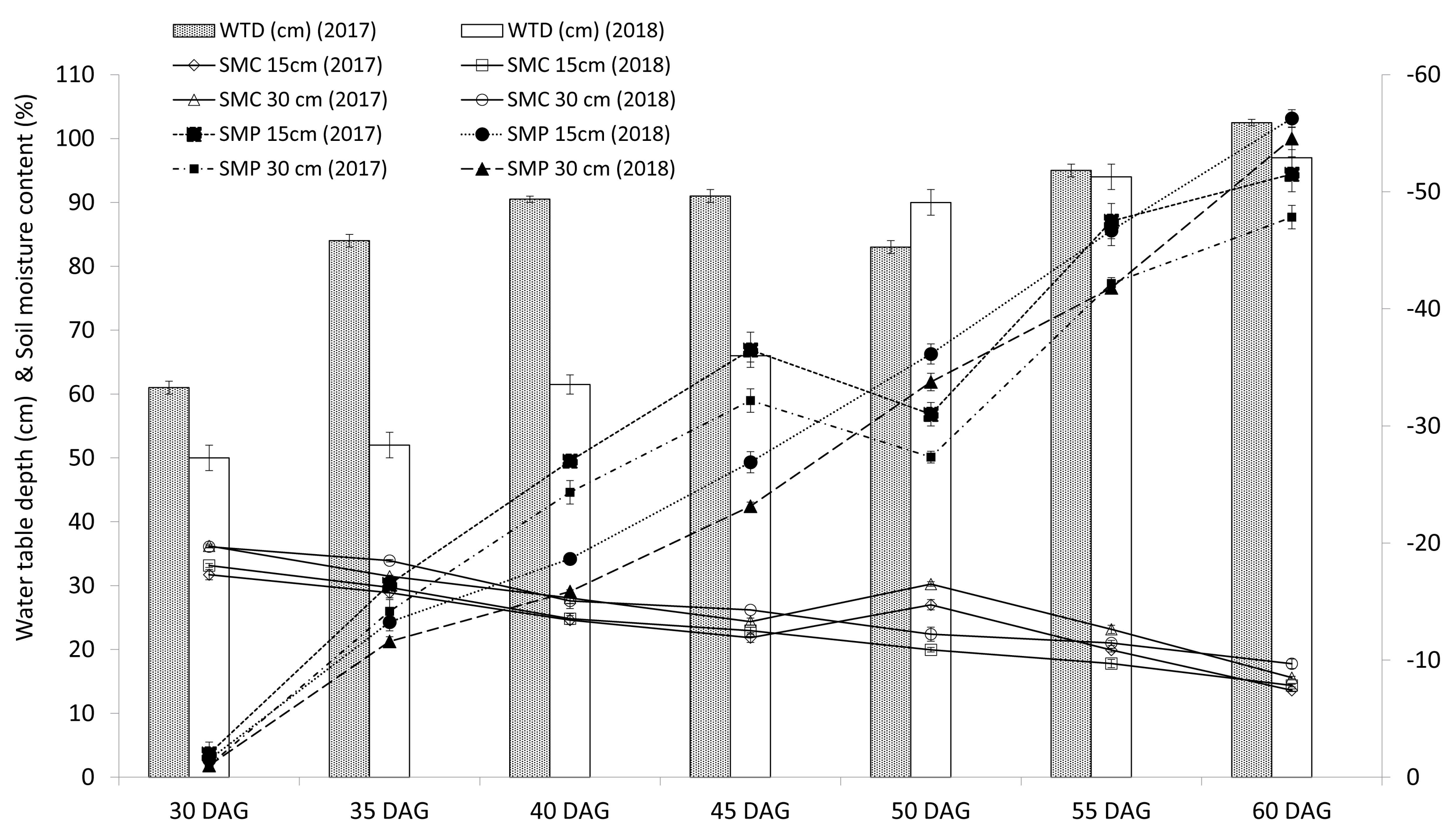




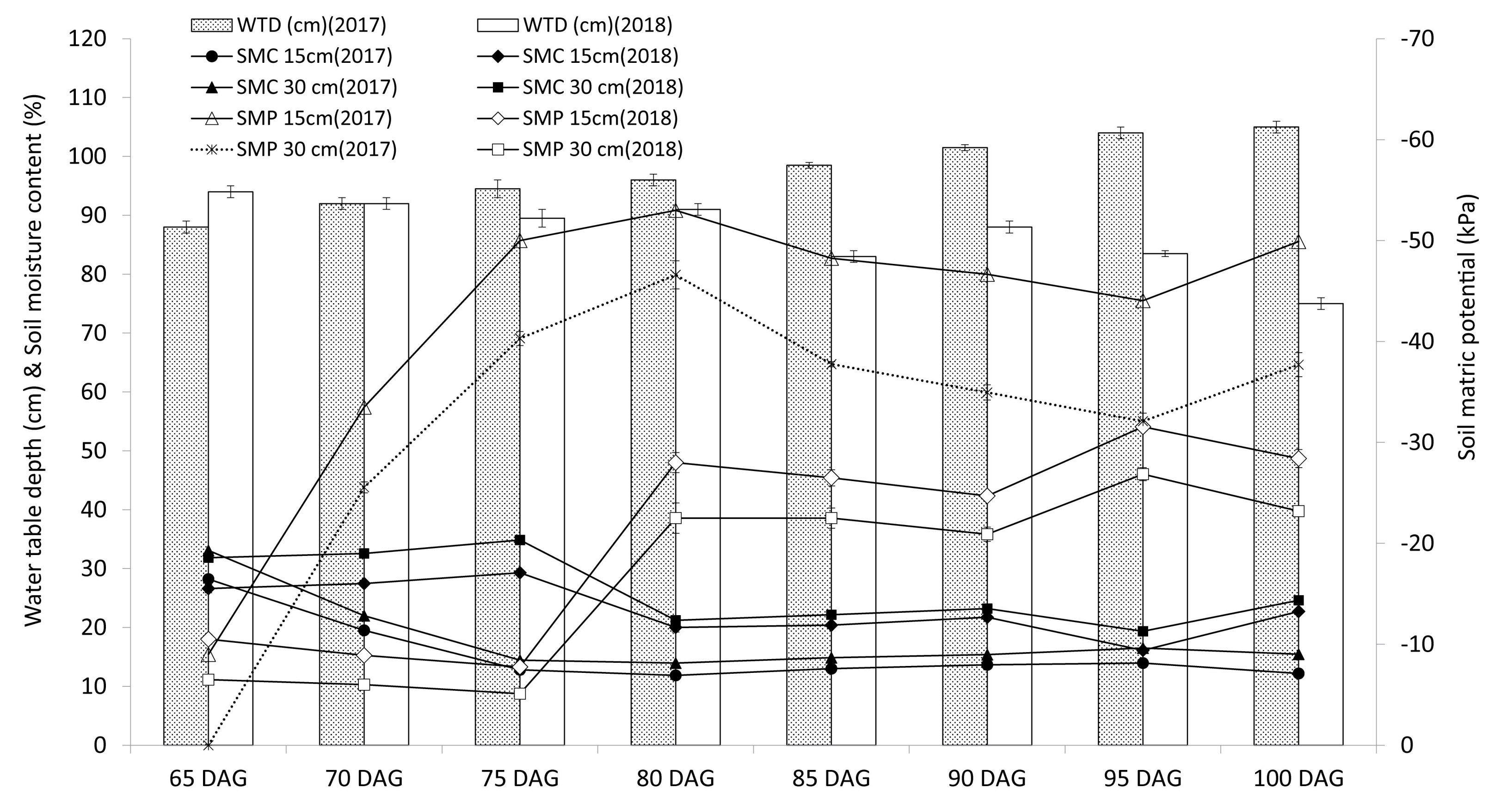









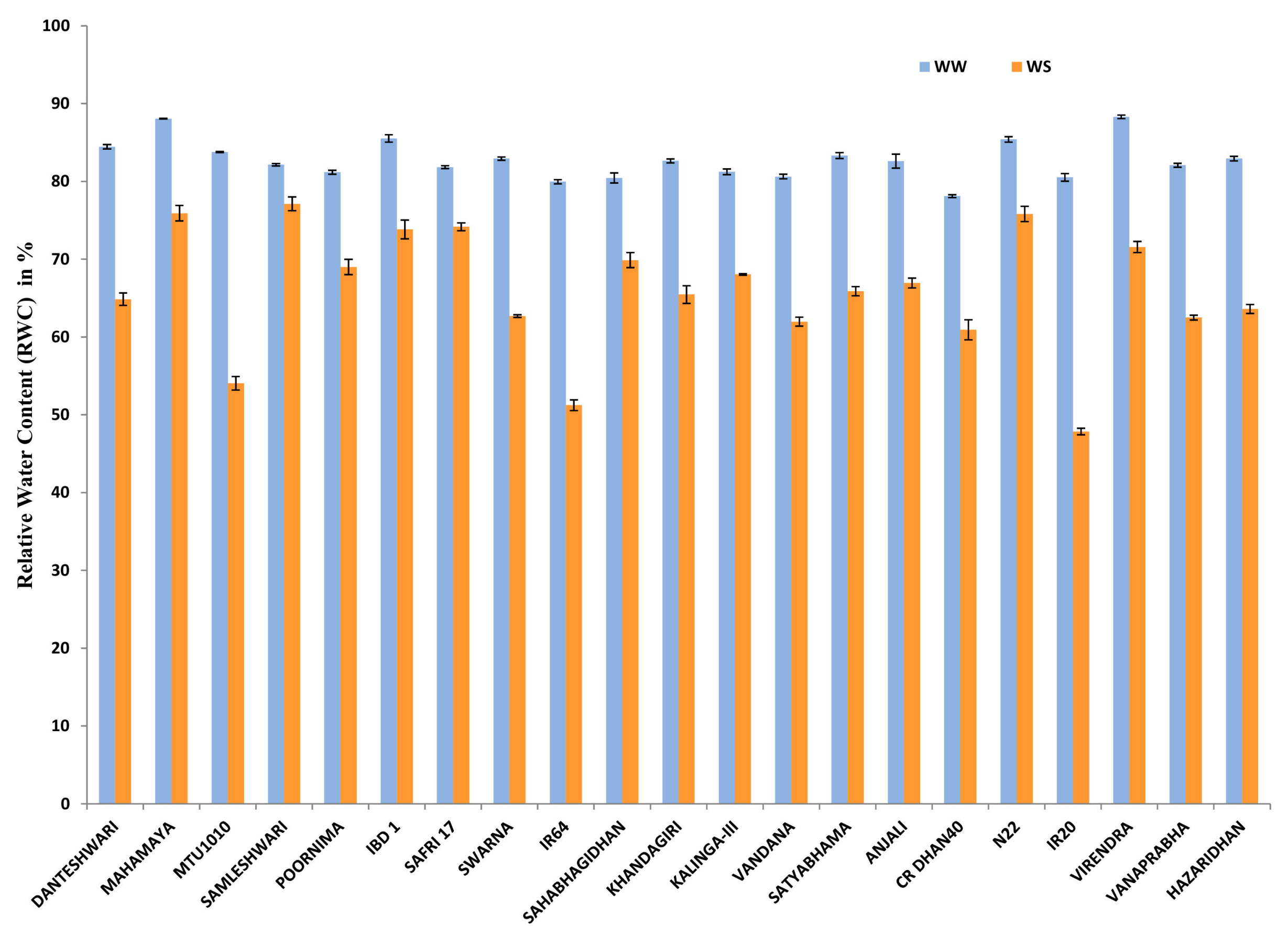








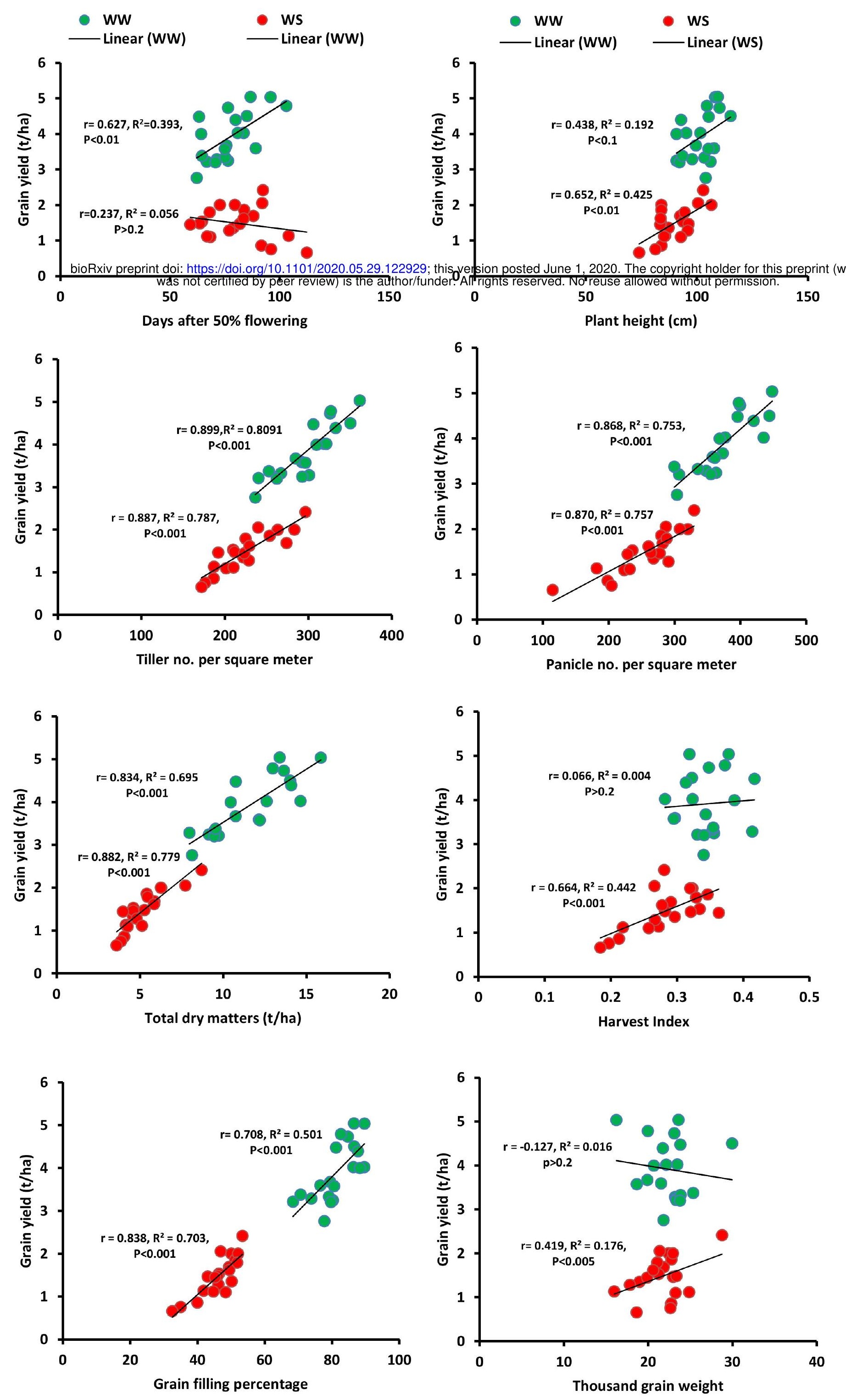




